Supporting Information

\title{
Partially Fluorinated Polyphenylene Ionomers as Proton Exchange Membranes for Fuel Cells: Effect of Pendant Multi- sulfophenylene Groups
}

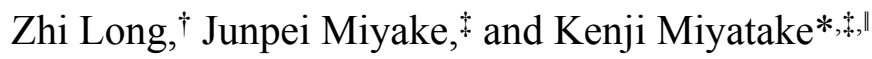

†nterdisciplinary Graduate School of Medicine and Engineering, University of Yamanashi, 4

Takeda, Kofu, Yamanashi 400-8510, Japan

tClean Energy Research Center, University of Yamanashi, 4 Takeda, Kofu, Yamanashi 4008510, Japan

"Fuel Cell Nanomaterials Center, University of Yamanashi, 4-3 Takeda, Kofu 400-8511, Japan

*Corresponding author

E-mail address: miyatake@yamanashi.ac.jp (K. Miyatake). 


\section{EXPERIMENTAL SECTION}

Materials. Phenylboronic acid (TCI), 4-biphenylboronic acid (TCI), 1-bromo-3,5dichlorobenzene (TCI), 1-bromo-2,5-dichlorobenzene (TCI), ethanol (KANTO Chemical), toluene (KANTO Chemical), palladium(II) acetate (TCI), tri(o-tolyl)phosphine (TCI), hexane (KANTO Chemical), dimethylacetamide (DMAc) (KANTO Chemical), oleum $\left(30 \% \mathrm{SO}_{3}\right)$ (KANTO Chemical), hydrochloric acid (KANTO Chemical), potassium carbonate $\left(\mathrm{K}_{2} \mathrm{CO}_{3}\right)$ (KANTO Chemical), 2,2'-bipyridine (TCI), bis(1,5-cyclooctadiene)nickel(0) (Ni(cod) $\left.)_{2}\right)$ (KANTO Chemical), lead(II) acetate $\left(\mathrm{Pb}(\mathrm{OAc})_{2}\right)$ trihydrate (KANTO Chemical) and sodium chloride $(\mathrm{NaCl})$ (KANTO Chemical) were purchased and used as received. 1,6Diiodoperfluorohexane was kindly supplied by Tosoh Finechem Co. Bis(3chlorophenyl)perfluorohexane (PAF monomer) and SPAF-MM were synthesized according to the literature.

All measurement conditions were similar to our previous report. ${ }^{1}$

Spectroscopy. ${ }^{1} \mathrm{H}(500 \mathrm{MHz}),{ }^{13} \mathrm{C}(125 \mathrm{MHz})$, and ${ }^{19} \mathrm{~F}(471 \mathrm{MHz}) \mathrm{NMR}$ spectra were obtained by a JEOL JNM-ECA 500 spectrometer using $\mathrm{CDCl}_{3}-d$, TCE- $d_{2}$ or DMSO- $d_{6}$ as a solvent and tetramethylsilane as an internal reference.

Titration. The ion exchange capacity (IEC) of the membranes was measured by acid/base titration at r.t. Ca. $20 \mathrm{mg}$ of dry membrane was immersed in $2 \mathrm{M} \mathrm{NaCl}$ aqueous solution for $24 \mathrm{~h}$ at r.t., and then was titrated with standard $0.01 \mathrm{M} \mathrm{NaOH}$ aqueous solution.

Molecular Weight Measurement. Gel permeation chromatography (GPC) with a UV detector (Jasco 805 UV), a Shodex K-805L column and DMF containing 0.01 M LiBr as eluent was used 
to estimate molecular weight of the polymers. Measurement was conducted at $50{ }^{\circ} \mathrm{C}$, and molecular weight was calibrated with standard polystyrene samples.

Morphology. For transmission electron microscopy (TEM), the membrane was stained in $0.5 \mathrm{M}$ $\mathrm{Pb}(\mathrm{OAc})_{2}$ aqueous solution, embedded in epoxy resin, sectioned to $50 \mathrm{~nm}$ thickness and placed on copper grids. Images were obtained via Hitachi H-9500 microscope with an accelerating voltage of $200 \mathrm{kV}$. The small angle X-ray scattering (SAXS) was measured by a Rigaku NANOViewer diffractometer equipped with a temperature/humidity-controllable chamber. The membrane (in $\mathrm{H}^{+}$form) was equilibrated for more than $2 \mathrm{~h}$ at a given relative humidity (RH) at $80{ }^{\circ} \mathrm{C}$.

Water Uptake and Proton Conductivity. Water uptake and in-plane proton conductivity of the membranes were measured simultaneously at $80{ }^{\circ} \mathrm{C}$ with a solid electrolyte analyzer system (MSBAD-V-FC, Bel Japan Co.) in a temperature/humidity-controllable chamber. The weight was measured by a magnetic suspension balance. The dry weight of a membrane was provided after drying at $80{ }^{\circ} \mathrm{C}$ in vacuo for $3 \mathrm{~h}$ and the wet weight was obtained after exposure to the testing humidity for more than $2 \mathrm{~h}$. The water uptake was calculated from the equation: (wet weight - dry weight)/dry weight $\times 100$. The in-plane proton conductivity was tested with a fourprobe conductivity cell connected with an ac impedance analyzer (Solartron 1255B and 1287, Solartron Inc.). Ion-conducting resistance was obtained in the frequency range of 1 to $10^{5} \mathrm{~Hz}$. The proton conductivity $(\delta)$ was calculated from the following equation: $\delta=1 /(\mathrm{A} \times \mathrm{R})$, where 1 is the distance between the two reference electrodes and $\mathrm{A}$ is the cross-sectional area.

Dynamic Mechanical Analysis (DMA). DMA was carried out with an ITK DVA-225 dynamic viscoelastic analyzer to evaluate the humidity dependence of the storage moduli ( $\left.\mathrm{E}^{\prime}\right)$, loss moduli $\left(\mathrm{E}^{\prime \prime}\right)$, and $\tan \delta\left(=\mathrm{E}^{\prime \prime} / \mathrm{E}^{\prime}\right)$ of the membranes. The sample was tested under a humidity range from 0 to $90 \% \mathrm{RH}$ at $80{ }^{\circ} \mathrm{C}$ at a humidification rate of $1 \% \mathrm{RH} \mathrm{min}^{-1}$. 
Tensile Test. The tensile property was measured with a Shimadzu AGS-J 500N universal testing instrument attached with a Toshin Kogyo Bethel-3A temperature/humidity-controllable chamber at $80{ }^{\circ} \mathrm{C}$ and $60 \%$ RH. Samples cut into a dumbbell shape [DIN-53504-S3, $35 \mathrm{~mm} \times 6 \mathrm{~mm}$ (total) and $12 \mathrm{~mm} \times 2 \mathrm{~mm}$ (test area)] were used. After equilibrating under the tested conditions for at least $2 \mathrm{~h}$, the stress-strain curves were obtained at a stretching rate of $10 \mathrm{~mm} \mathrm{~min}^{-1}$.

Preparation of Catalyst-Coated Membrane (CCM). A catalyst paste was prepared by mixing Pt/CB catalyst (TEC10E50E, Tanaka Kikinzoku Kogyo K. K.), Nafion dispersion (IEC = 0.951.03 meq g $\mathrm{g}^{-1}$, D-521, Du Pont), deionized water and ethanol by ball milling for $30 \mathrm{~min}$. The mass ratio of Nafion ionomer to the carbon support (I/C) was adjusted to 0.7. Catalyst-coated membranes (CCMs) were prepared by spraying the catalyst paste on both sides of the membrane (SPAF-MM or SPAF-BM) by pulse swirl spray (PSS) technique. The CCMs were dried at $60^{\circ} \mathrm{C}$ overnight and hot-pressed at $140{ }^{\circ} \mathrm{C}$ and $1.0 \mathrm{MPa}$ for $3 \mathrm{~min}$. The geometric area and the $\mathrm{Pt}$ loading amount in the catalyst layer (CL) were $4.41 \mathrm{~cm}^{2}$ and $0.50 \pm 0.02 \mathrm{mg} \mathrm{cm}^{-2}$, respectively.

Fuel Cell Operation. Linear sweep voltammetry (LSV) was measured to evaluate the permeability of hydrogen gas from the anode to the cathode through the ionomer membranes. LSV measurement was carried out at 30 or $100 \% \mathrm{RH}$ and $80{ }^{\circ} \mathrm{C}$. Prior to the LSV measurements, $\mathrm{H}_{2}(100 \mathrm{~mL} \mathrm{~min}-1)$ and $\mathrm{N}_{2}\left(100 \mathrm{~mL} \mathrm{m^{-1 }}\right)$ were supplied to the anode and the cathode, respectively. The cathode potential was swept from 0.15 to $0.6 \mathrm{~V}$ at a sweep rate of $0.5 \mathrm{mV} \mathrm{s}^{-1}$. To evaluate the cell performance, the polarization (IV) curves were measured at 30 or $100 \% \mathrm{RH}$ and $80{ }^{\circ} \mathrm{C}$. Pure $\mathrm{H}_{2}$ and $\mathrm{O}_{2}$ (or air) were supplied to the anode and the cathode, respectively. The gas utilizations at the anode and the cathode were $70 \%$ and $40 \%$, respectively. The high frequency resistance (HFR) of the cell was measured with a digital ac milliohmmeter (Model 3356 Tsuruga Electric Corporation) at $1.0 \mathrm{kHz}$. The open circuit voltage (OCV) hold test was 
carried out at $80{ }^{\circ} \mathrm{C}$ and $30 \% \mathrm{RH}$ with $\mathrm{H}_{2}$ for the anode and air for the cathode, respectively, at a gas flow rate of $100 \mathrm{~mL} \mathrm{~min}^{-1}$. The OCV hold test was continued for $1000 \mathrm{~h}$. 
Scheme S1. Synthesis of 3,5-dichlorobiphenyl.
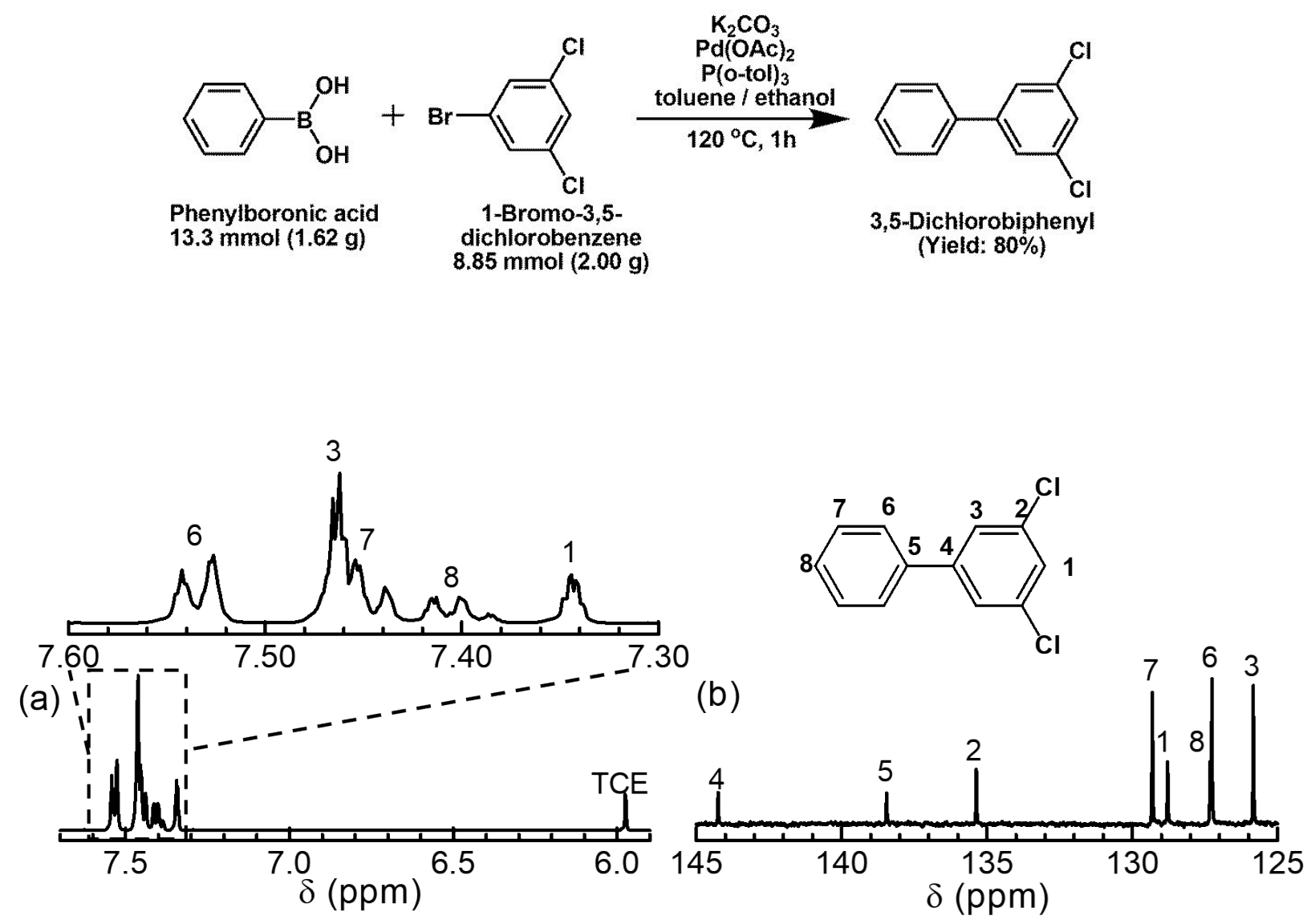

Figure S1. (a) ${ }^{1} \mathrm{H}$ and (b) ${ }^{13} \mathrm{C}$ NMR spectra of 3,5-dichlorobiphenyl in TCE- $d_{2}$ at r.t. 
Scheme S2. Synthesis of 2,5-dichlorobiphenyl.
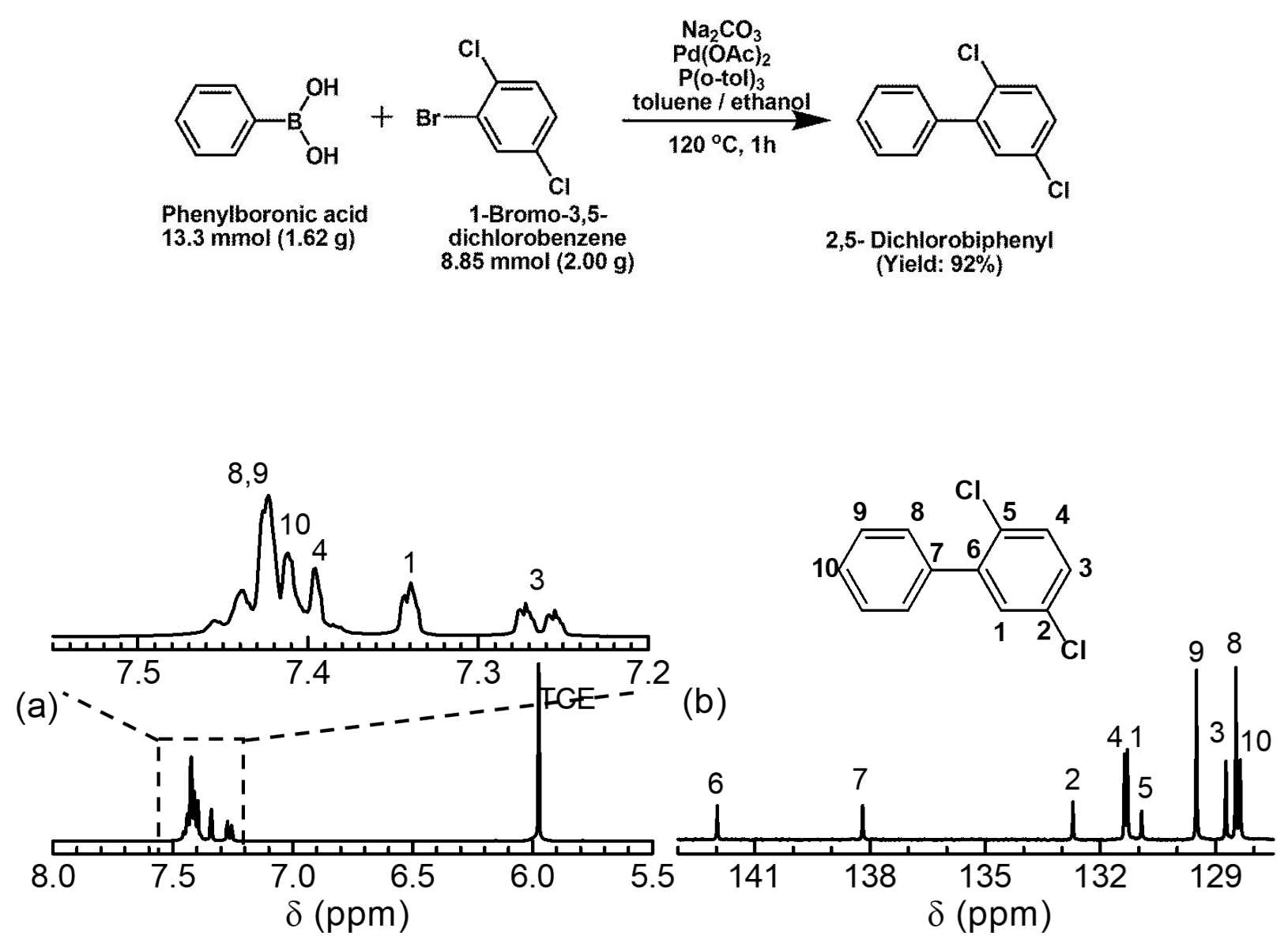

Figure S2. (a) ${ }^{1} \mathrm{H}$ and (b) ${ }^{13} \mathrm{C}$ NMR spectra of 2,5-dichlorobiphenyl in TCE- $d_{2}$ at r.t. 
Scheme S3. Synthesis of 3,5-dichloro-p-terphenyl.
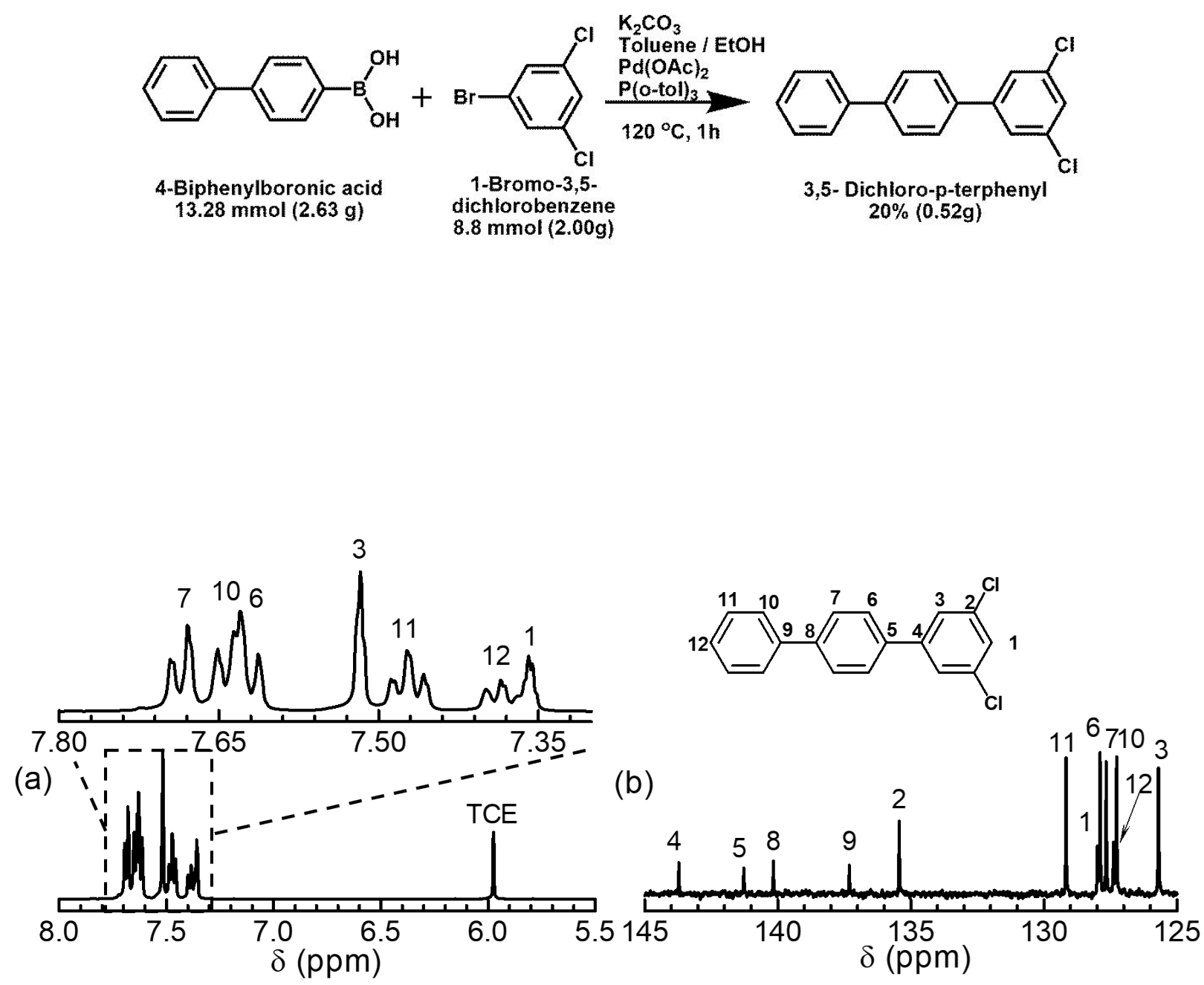

Figure S3. (a) ${ }^{1} \mathrm{H}$ and (b) ${ }^{13} \mathrm{C}$ NMR spectra of 3,5-dichloro-p-terphenyl in TCE- $d_{2}$ at r.t. 
Scheme S4. Synthesis of 2,5-dichloro-p-terphenyl

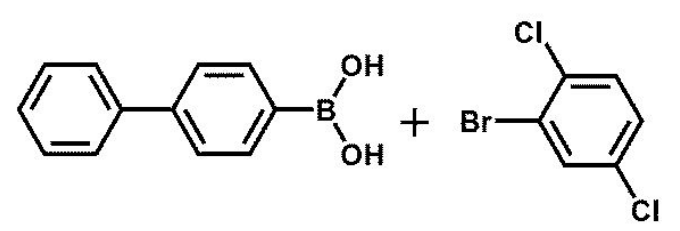

4-Biphenylboronic acid $13.28 \mathrm{mmol}(2.63 \mathrm{~g})$
1-Bromo-2,5dichlorobenzene $8.8 \mathrm{mmol}(2.00 \mathrm{~g})$

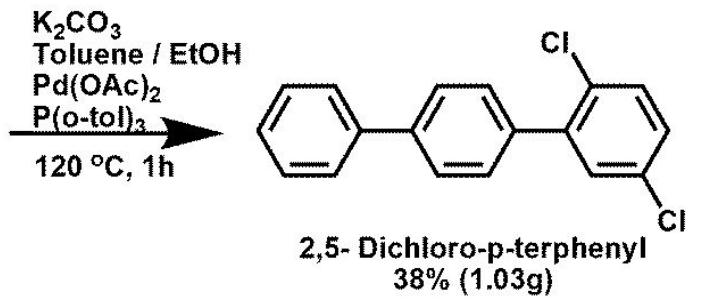

$\mathrm{K}_{2} \mathrm{CO}_{3}$

Toluene / EtOH

$\mathrm{Pd}(\mathrm{OAC})_{2}$

$\mathrm{P}(\mathrm{O}-\mathrm{(ol})_{3}$
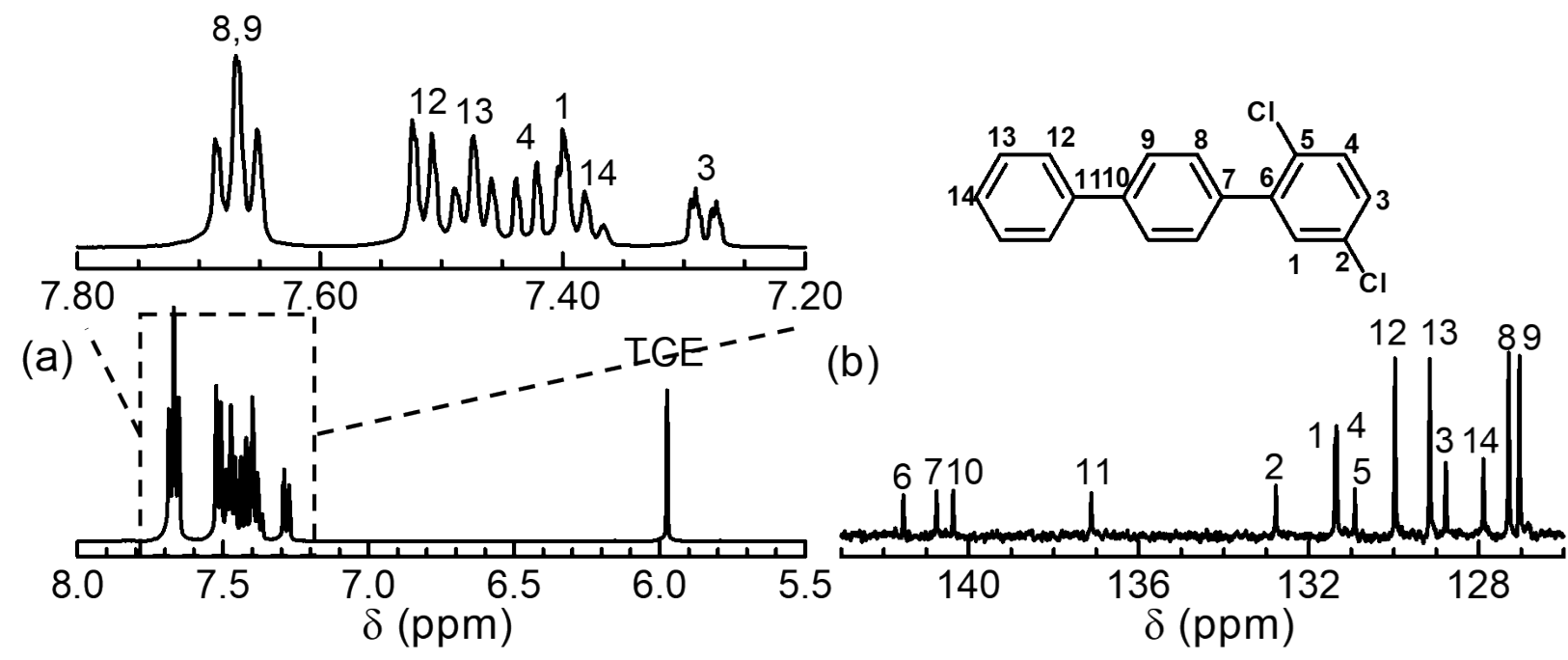

Figure S4. (a) ${ }^{1} \mathrm{H}$ and (b) ${ }^{13} \mathrm{C}$ NMR spectra of 2,5-dichloro- $p$-terphenyl in TCE- $d_{2}$ at r.t. 
Table S1. Molecular Weight and Yield of PAF polymers ${ }^{a}$

\begin{tabular}{ccccc}
\hline polymer & $M_{\mathrm{n}}{ }^{b}(\mathrm{kDa})$ & $M_{\mathrm{w}}{ }^{b}(\mathrm{kDa})$ & $M_{\mathrm{w}} / M_{\mathrm{n}}$ & yield (\%) \\
\hline PAF-MM & 19.8 & 65.3 & 3.28 & 84 \\
PAF-BM & 19.8 & 65.0 & 3.28 & 99 \\
PAF-MB & 19.3 & 79.2 & 4.11 & 88 \\
PAF-BB & 27.0 & 76.9 & 2.85 & 92 \\
PAF-TM & 23.0 & 102 & 4.44 & 89 \\
PAF-MT & 11.8 & 38.0 & 3.22 & 88 \\
PAF-TT & 15.2 & 37.6 & 2.48 & 92 \\
\hline
\end{tabular}

${ }^{a}$ In all cases, the feed molar ratio of m:n:o for polymerization was set to be 1:0.48:0.62. ${ }^{b}$ Determined by GPC. 


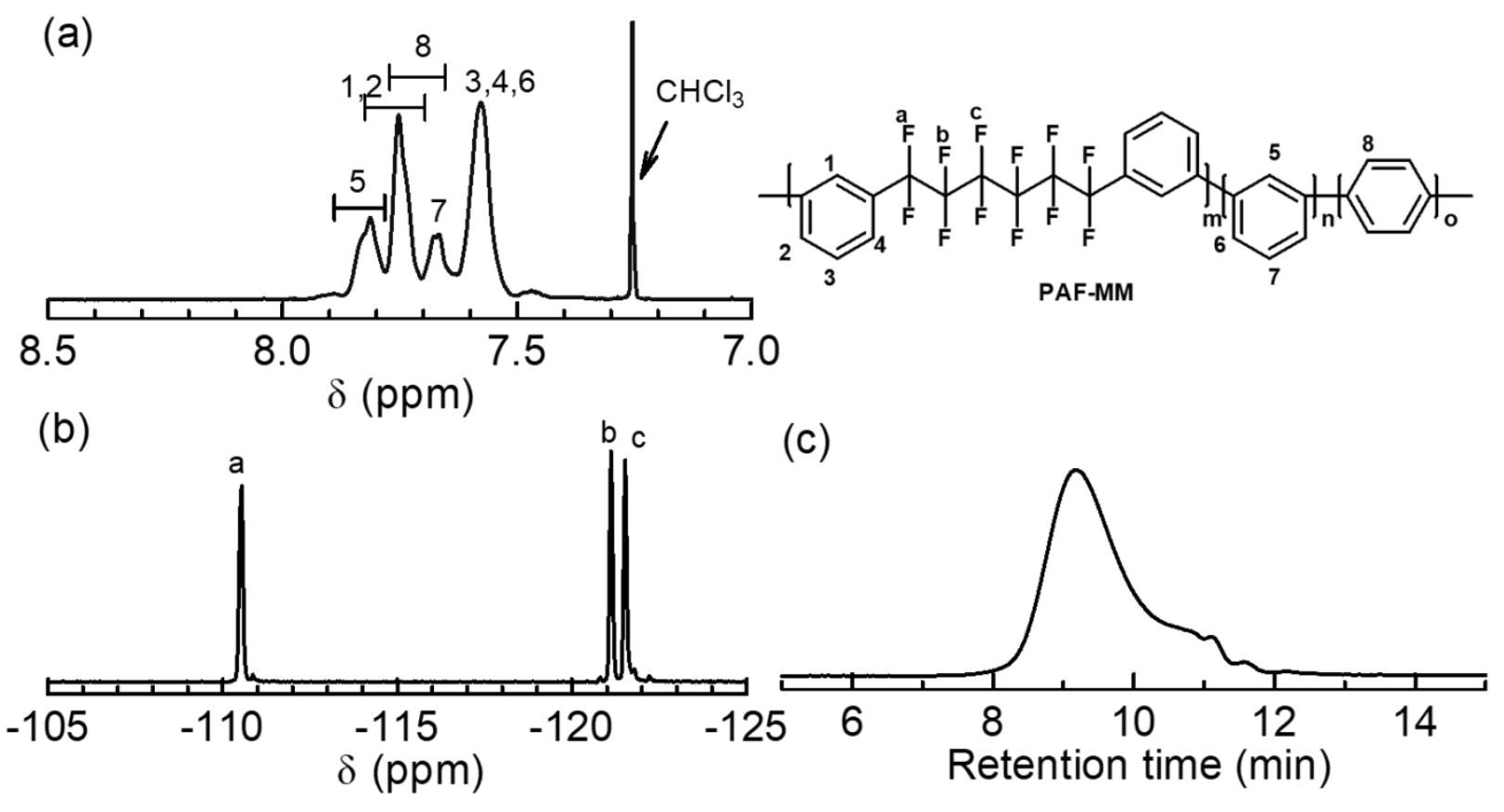

Figure S5. (a) ${ }^{1} \mathrm{H}$ and (b) ${ }^{19} \mathrm{~F}$ NMR spectra in $\mathrm{CDCl}_{3}$ at r.t. and (c) GPC profile of PAF-MM. 


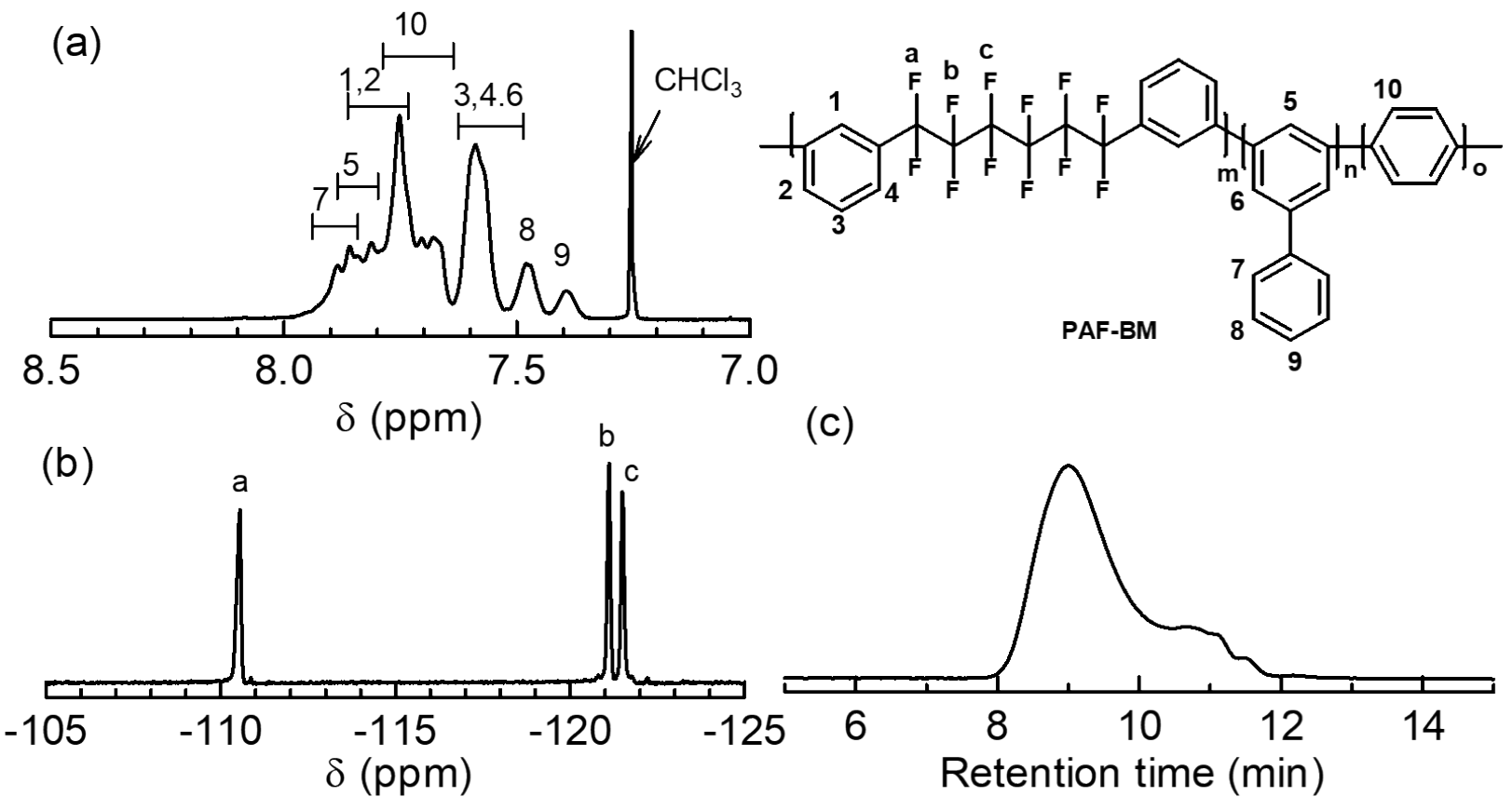

Figure S6. (a) ${ }^{1} \mathrm{H}$ and (b) ${ }^{19} \mathrm{~F}$ NMR spectra in $\mathrm{CDCl}_{3}$ at r.t. and (c) GPC profile of PAF-BM. 


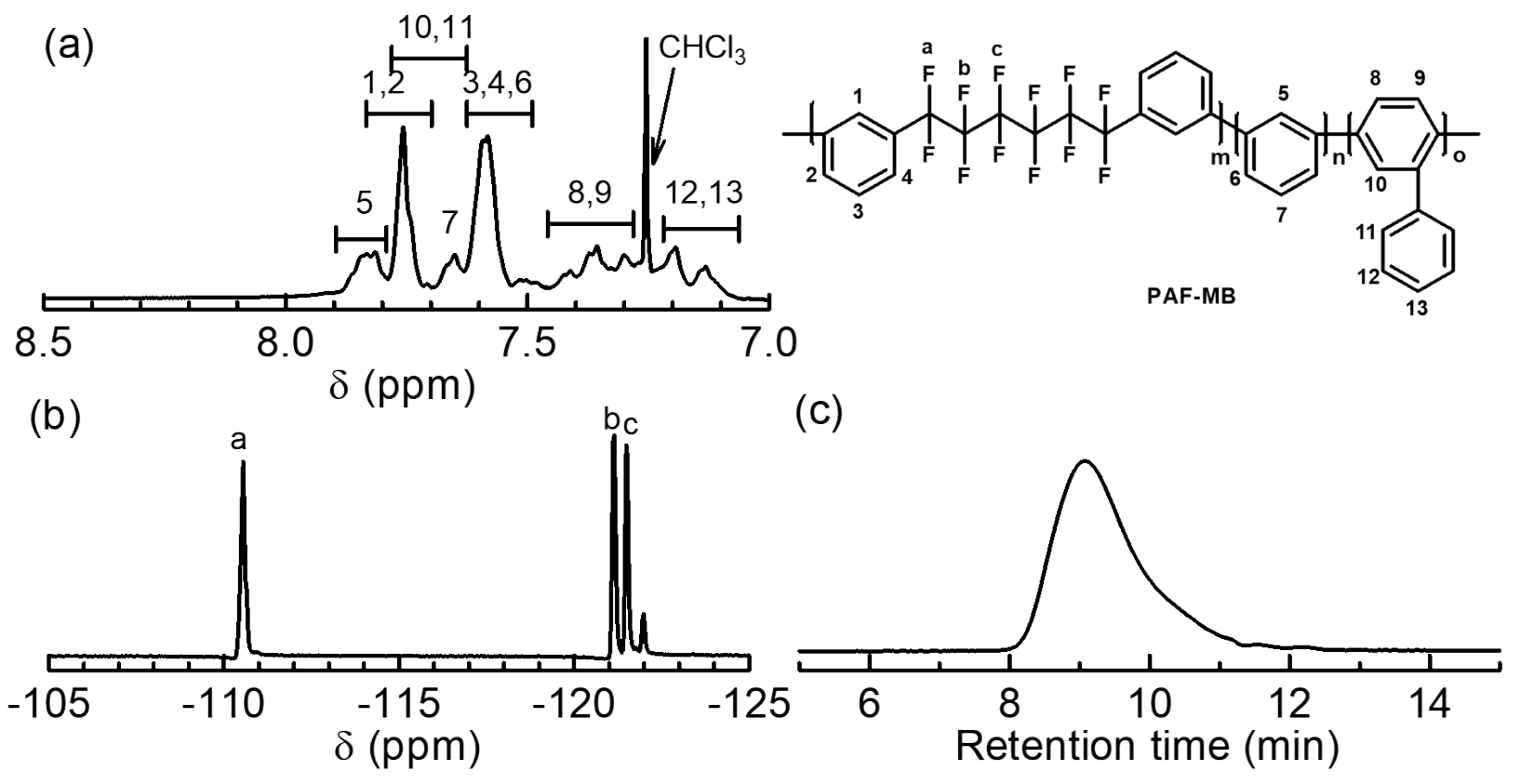

Figure S7. (a) ${ }^{1} \mathrm{H}$ and (b) ${ }^{19} \mathrm{~F}$ NMR spectra in $\mathrm{CDCl}_{3}$ at r.t. and (c) GPC profile of PAF-MB. 


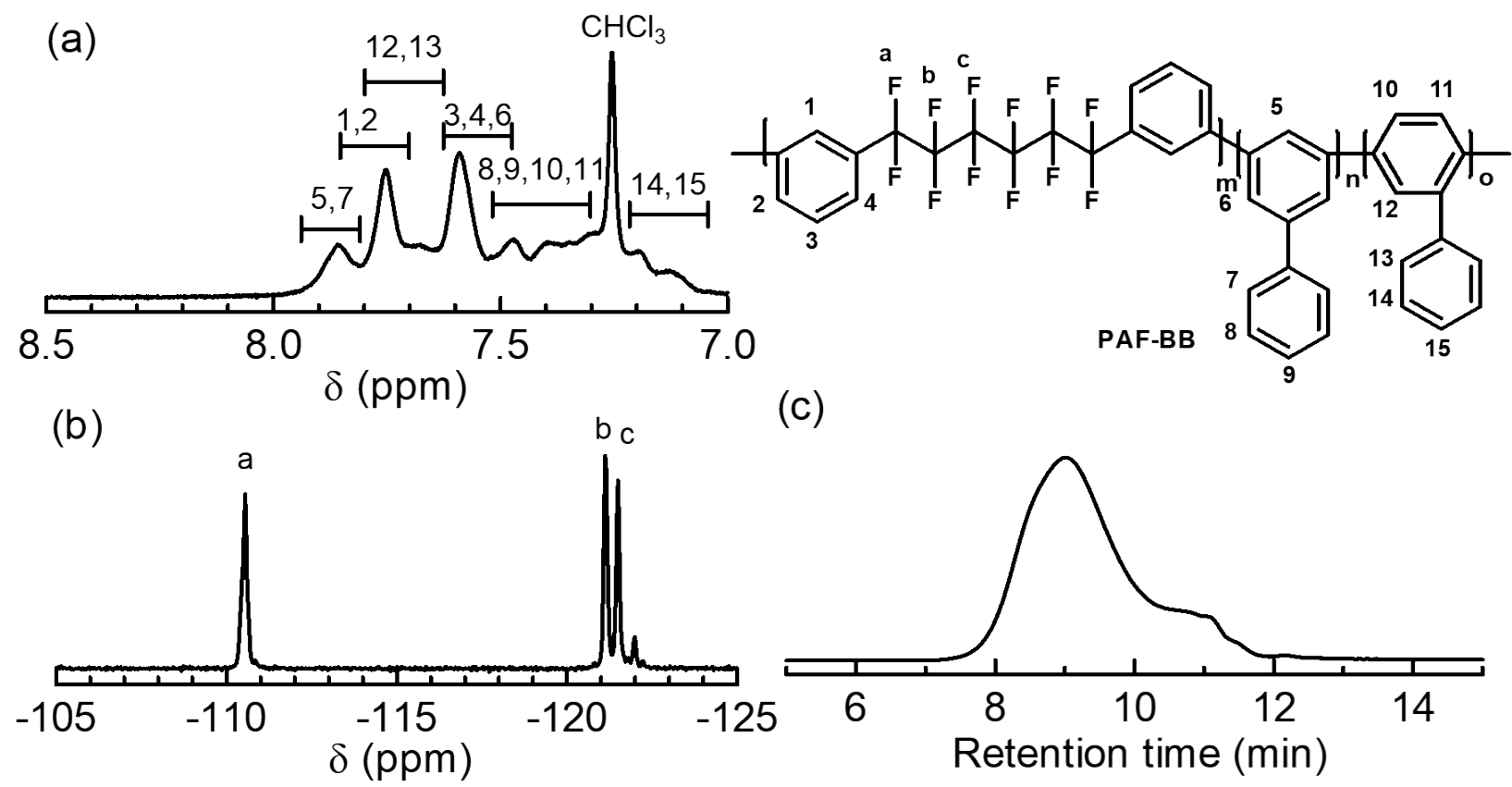

|Figure S8. (a) ${ }^{1} \mathrm{H}$ and (b) ${ }^{19} \mathrm{~F}$ NMR spectra in $\mathrm{CDCl}_{3}$ at r.t. and (c) GPC profile of PAF-BB. 


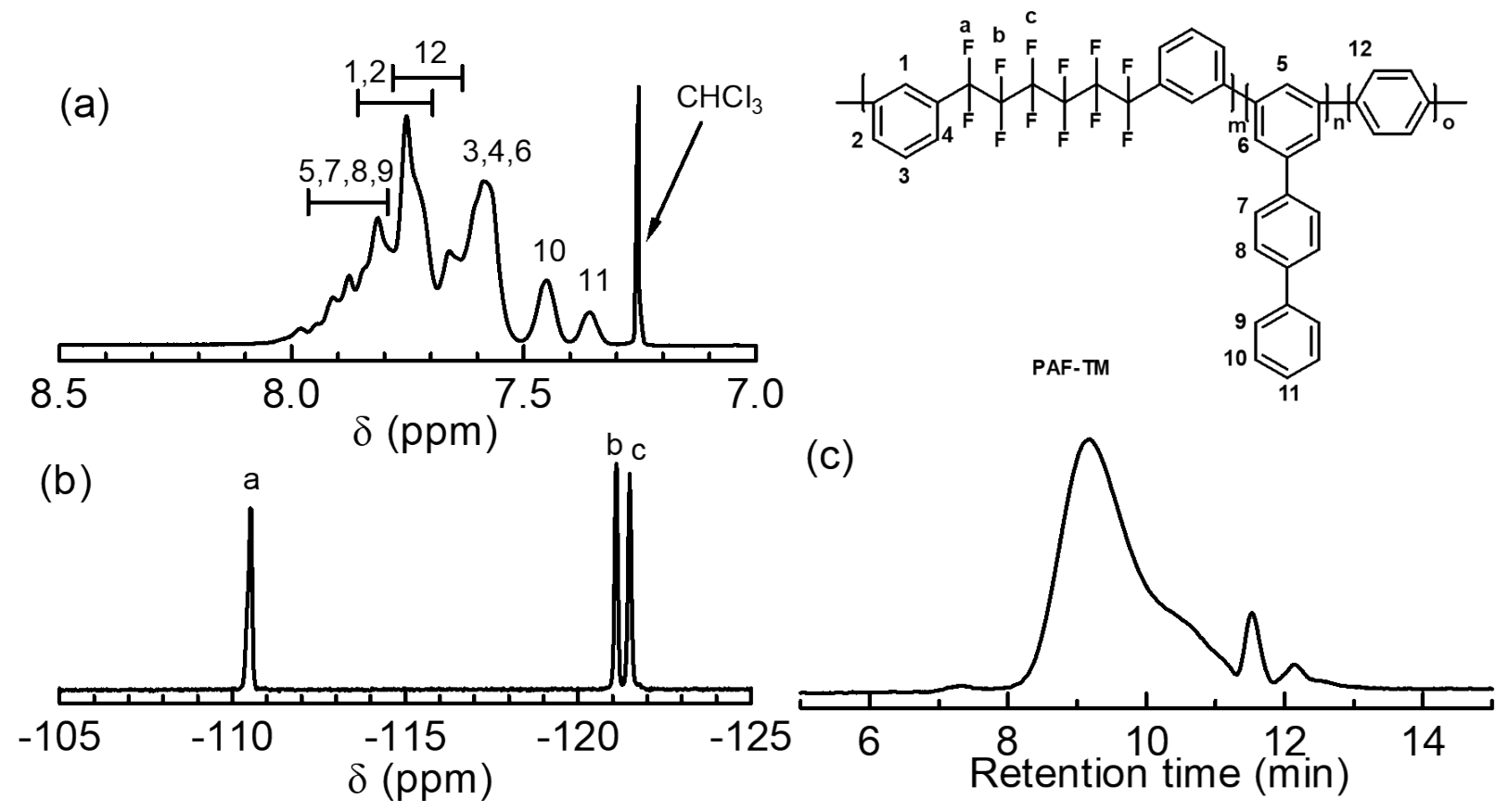

Figure S9. (a) ${ }^{1} \mathrm{H}$ and (b) ${ }^{19} \mathrm{~F}$ NMR spectra in $\mathrm{CDCl}_{3}$ at r.t. and (c) GPC profile of PAF-TM. 


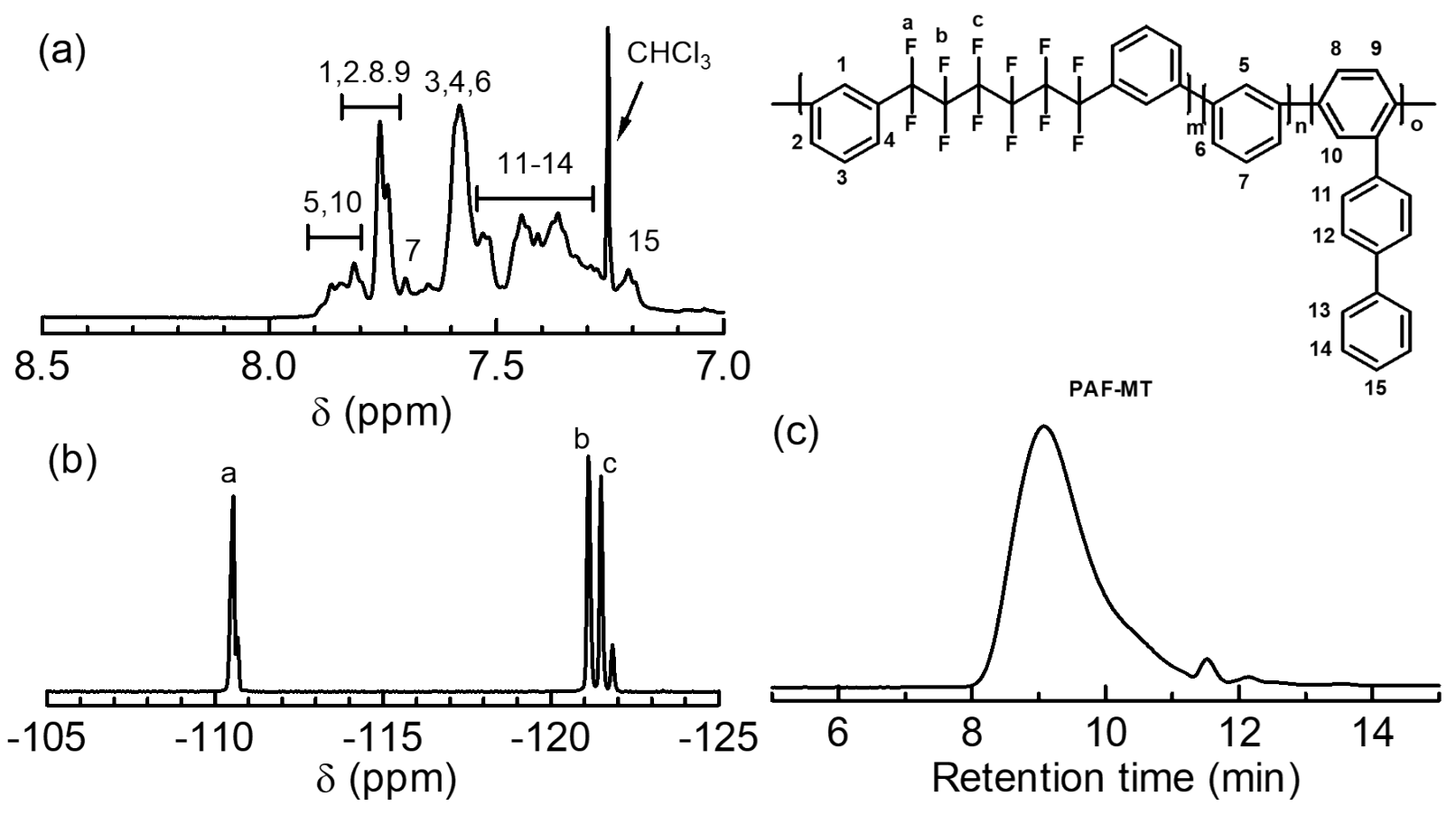

Figure S10. (a) ${ }^{1} \mathrm{H}$ and (b) ${ }^{19} \mathrm{~F}$ NMR spectra in $\mathrm{CDCl}_{3}$ at r.t. and (c) GPC profile of PAF-MT. 

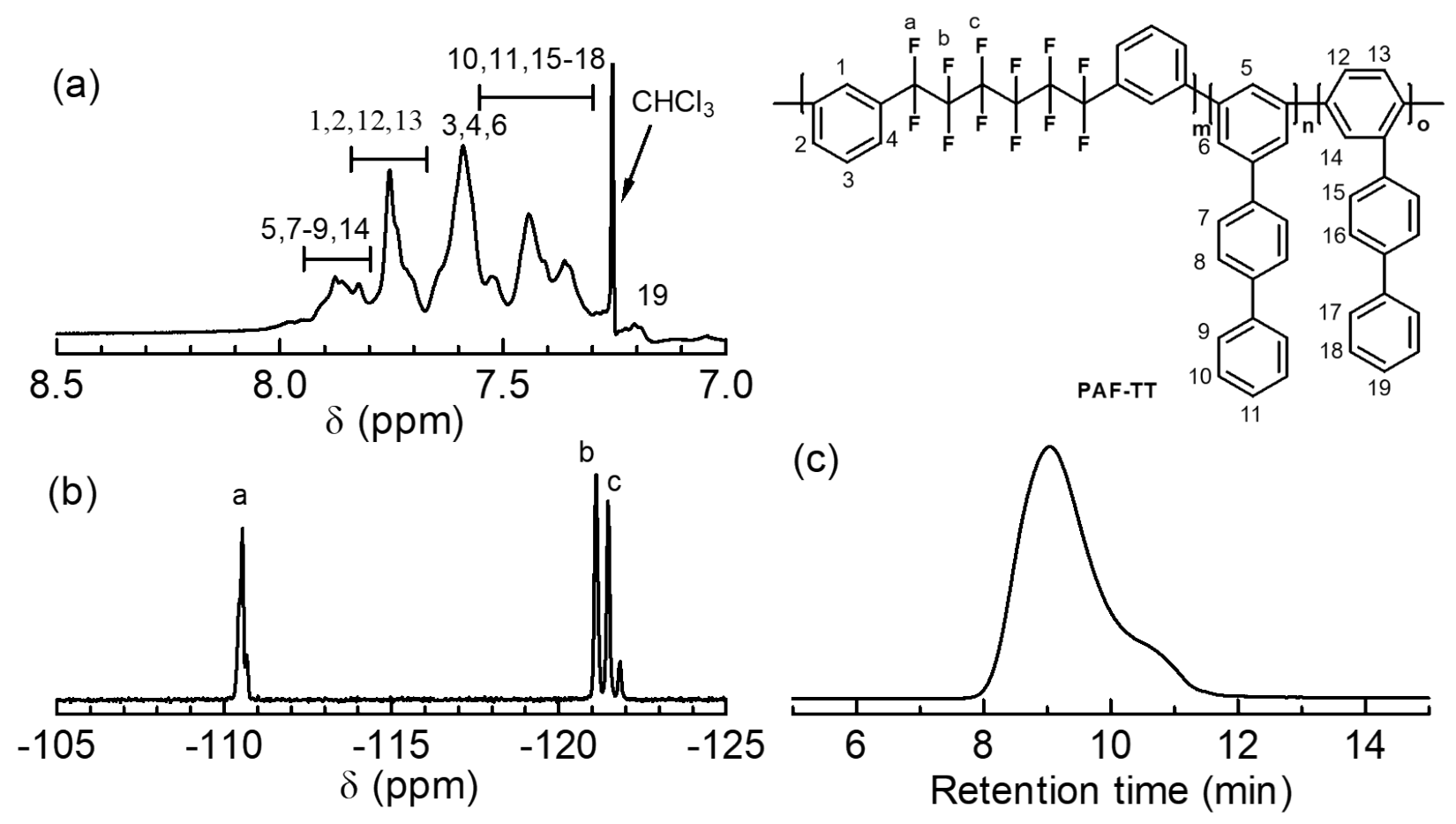

Figure S11. (a) ${ }^{1} \mathrm{H}$ and (b) ${ }^{19} \mathrm{~F}$ NMR spectra in $\mathrm{CDCl}_{3}$ at r.t. and (c) GPC profile of PAF-TT. 


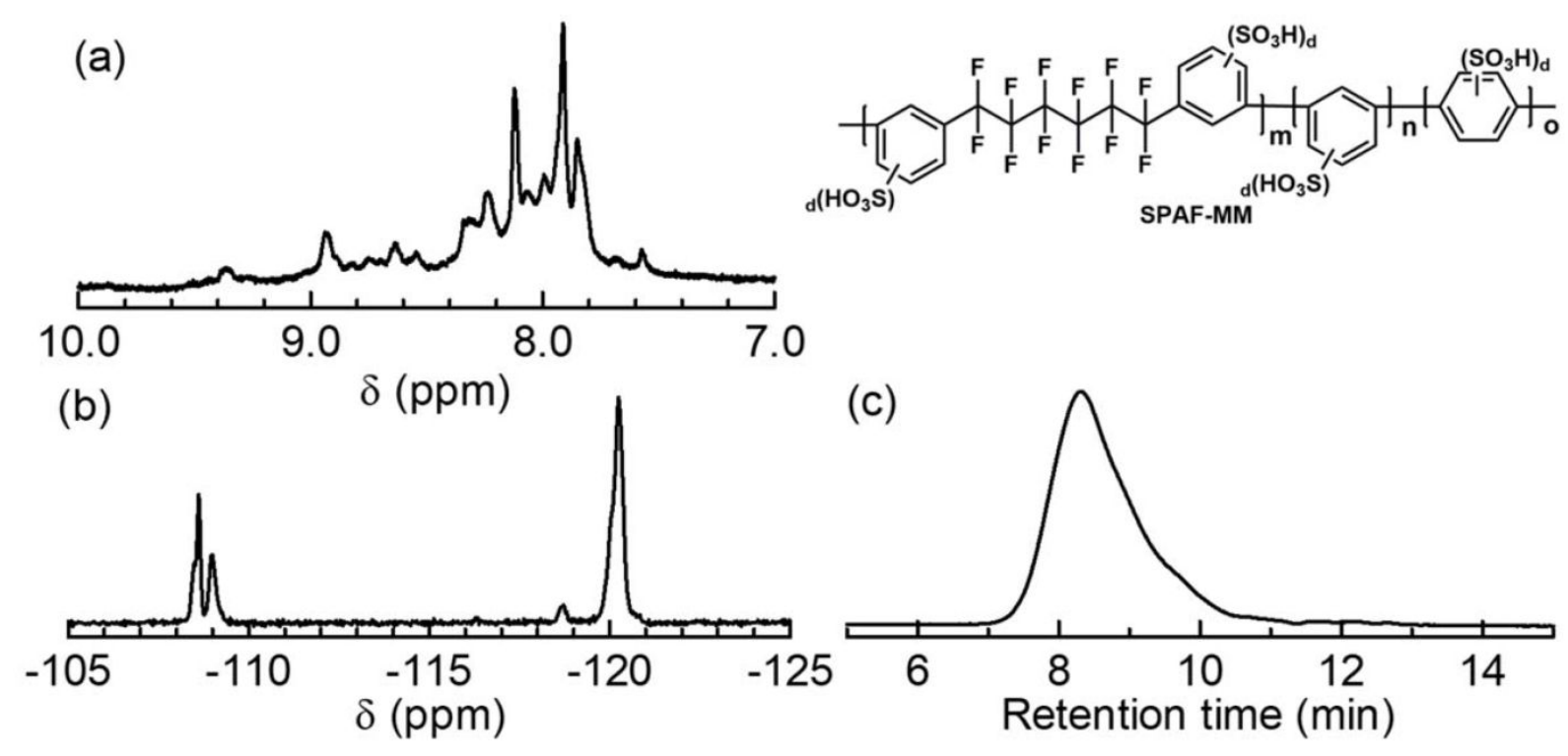

Figure S12. (a) ${ }^{1} \mathrm{H}$ and (b) ${ }^{19} \mathrm{~F}$ NMR spectra in DMSO- $d_{6}$ at $80{ }^{\circ} \mathrm{C}$ and (c) GPC profile of SPAFMM. 

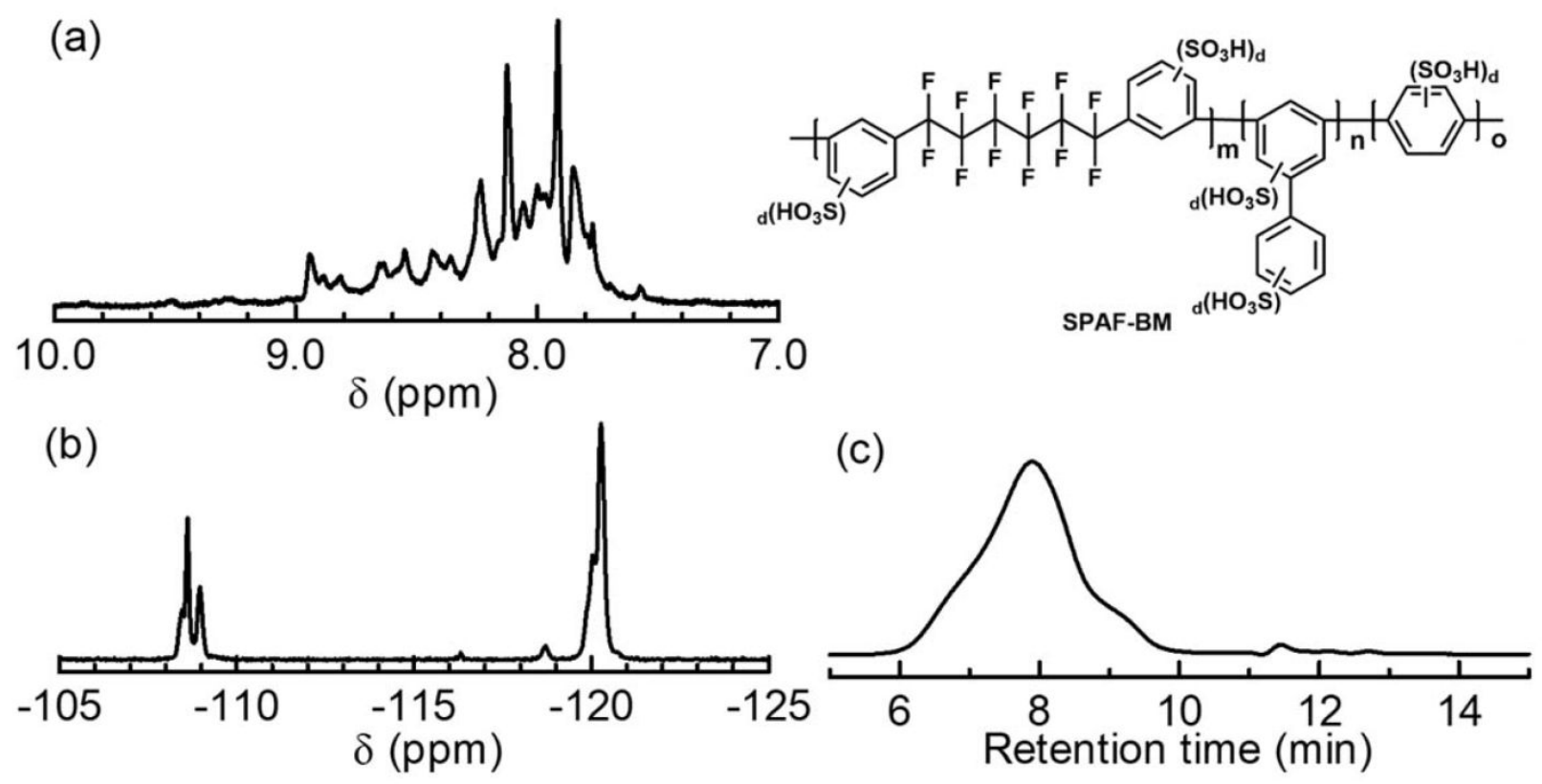

Figure S13. (a) ${ }^{1} \mathrm{H}$ and (b) ${ }^{19} \mathrm{~F}$ NMR spectra in DMSO- $d_{6}$ at $80{ }^{\circ} \mathrm{C}$ and (c) GPC profile of SPAFBM. 


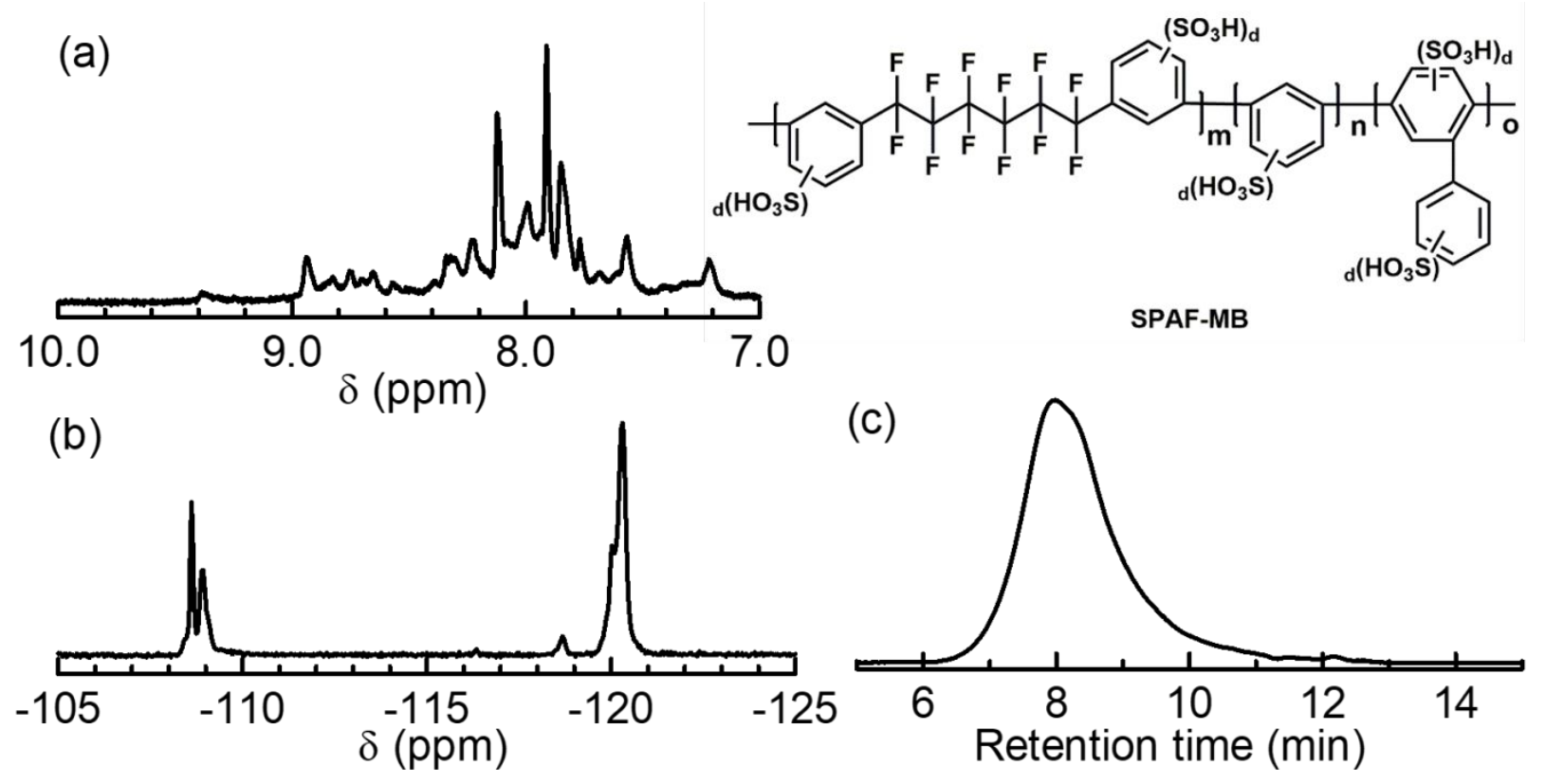

Figure S14. (a) ${ }^{1} \mathrm{H}$ and (b) ${ }^{19} \mathrm{~F}$ NMR spectra in DMSO- $d_{6}$ at $80{ }^{\circ} \mathrm{C}$ and (c) GPC profile of SPAFMB. 


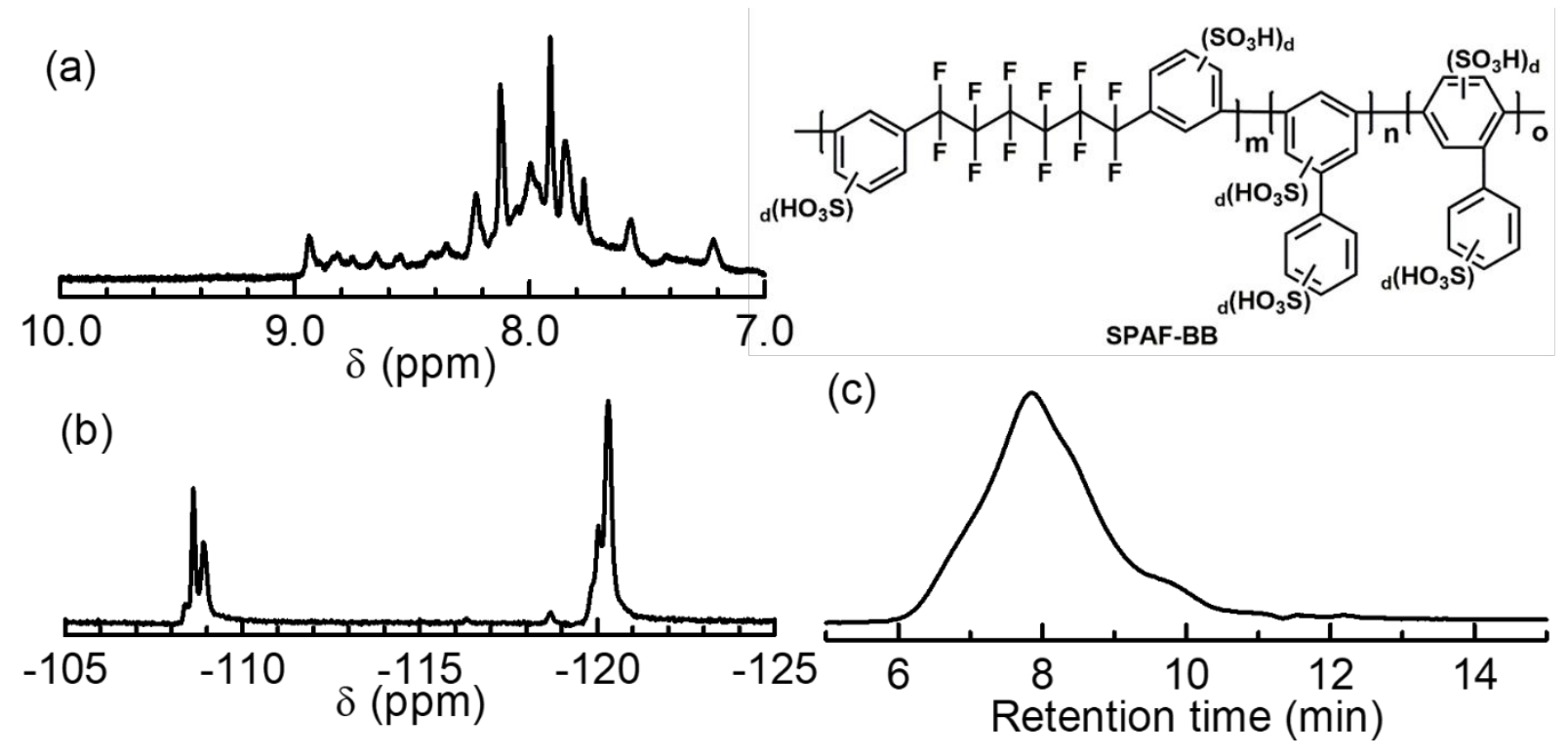

Figure S15. (a) ${ }^{1} \mathrm{H}$ and (b) ${ }^{19} \mathrm{~F}$ NMR spectra in DMSO- $d_{6}$ at $80{ }^{\circ} \mathrm{C}$ and (c) GPC profile of SPAFBB. 


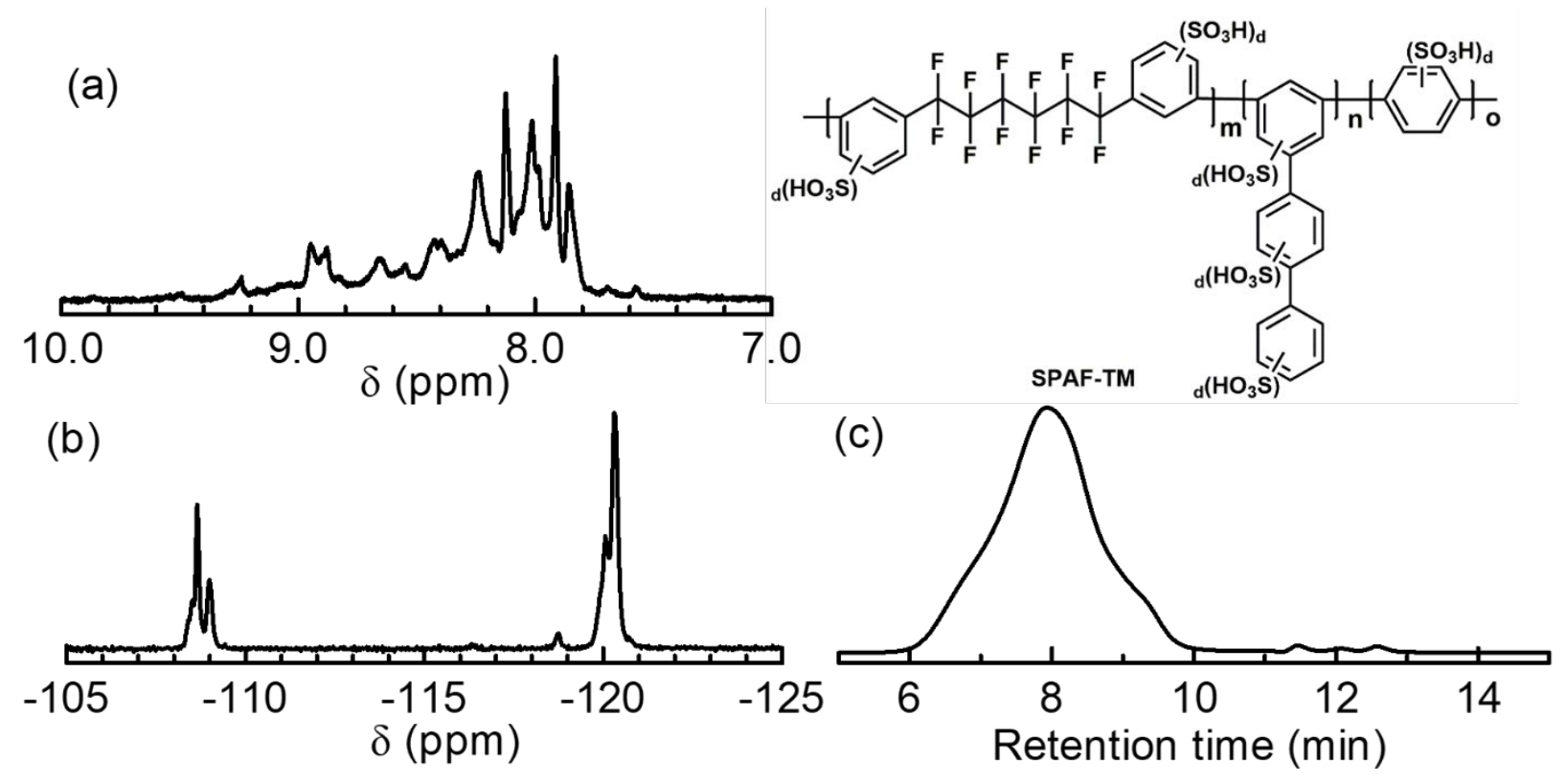

Figure S16. (a) ${ }^{1} \mathrm{H}$ and (b) ${ }^{19} \mathrm{~F}$ NMR spectra in DMSO- $d_{6}$ at $80{ }^{\circ} \mathrm{C}$ and (c) GPC profile of SPAFTM. 

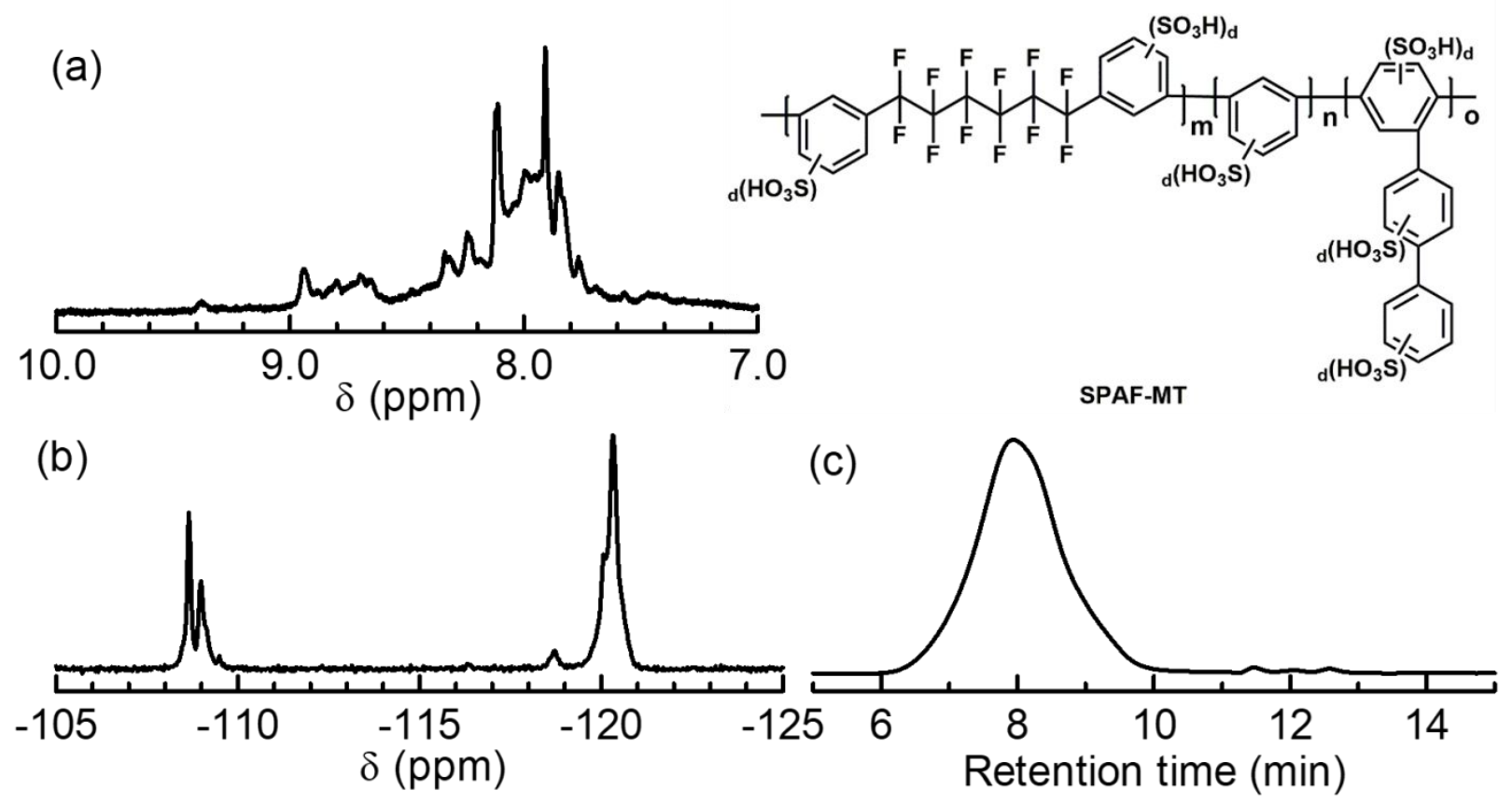

Figure S17. (a) ${ }^{1} \mathrm{H}$ and (b) ${ }^{19} \mathrm{~F}$ NMR spectra in DMSO- $d_{6}$ at $80{ }^{\circ} \mathrm{C}$ and (c) GPC profile of SPAFMT. 


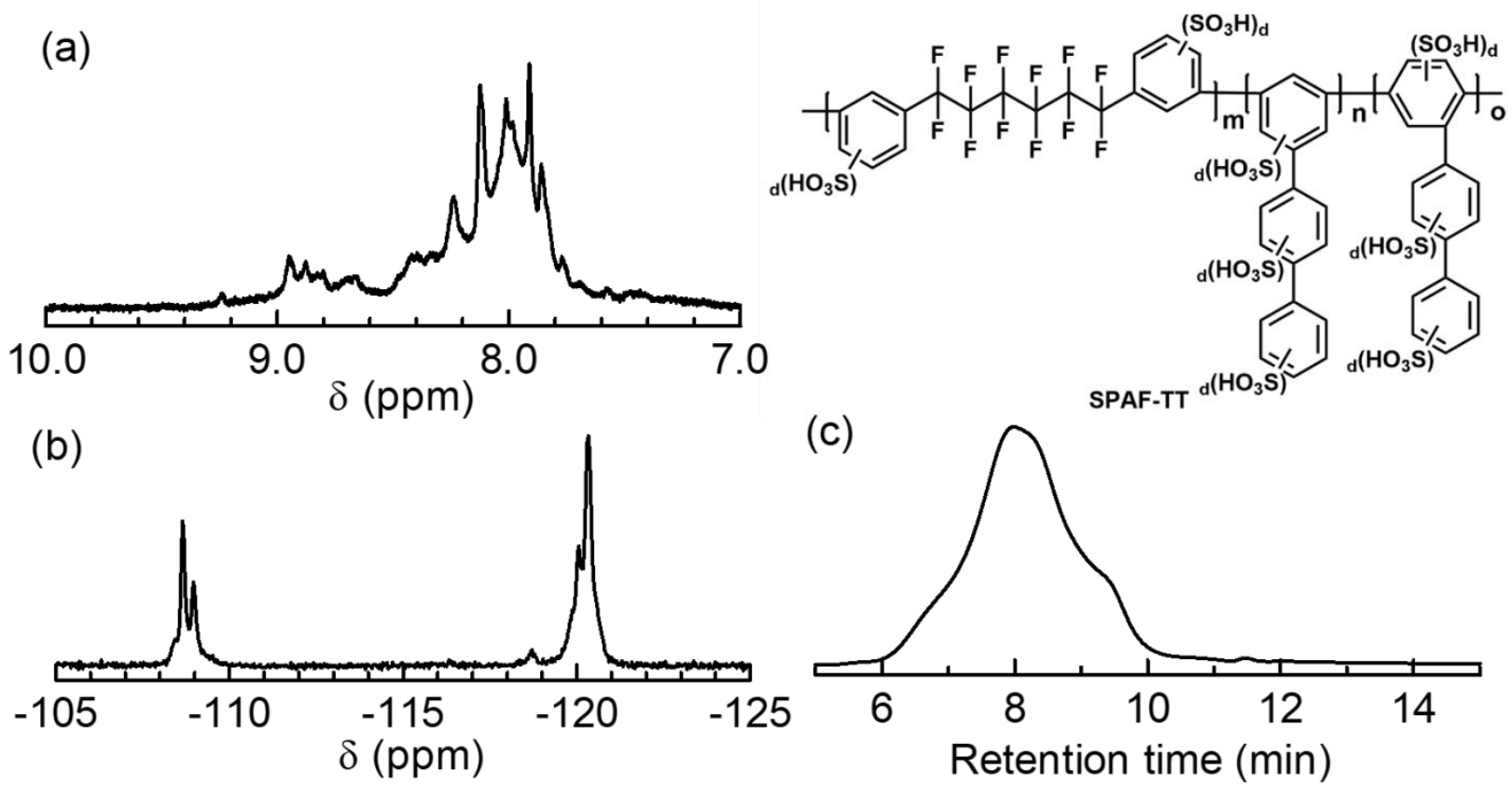

Figure S18. (a) ${ }^{1} \mathrm{H}$ and (b) ${ }^{19} \mathrm{~F}$ NMR spectra in DMSO- $d_{6}$ at $80{ }^{\circ} \mathrm{C}$ and (c) GPC profile of SPAFTT. 


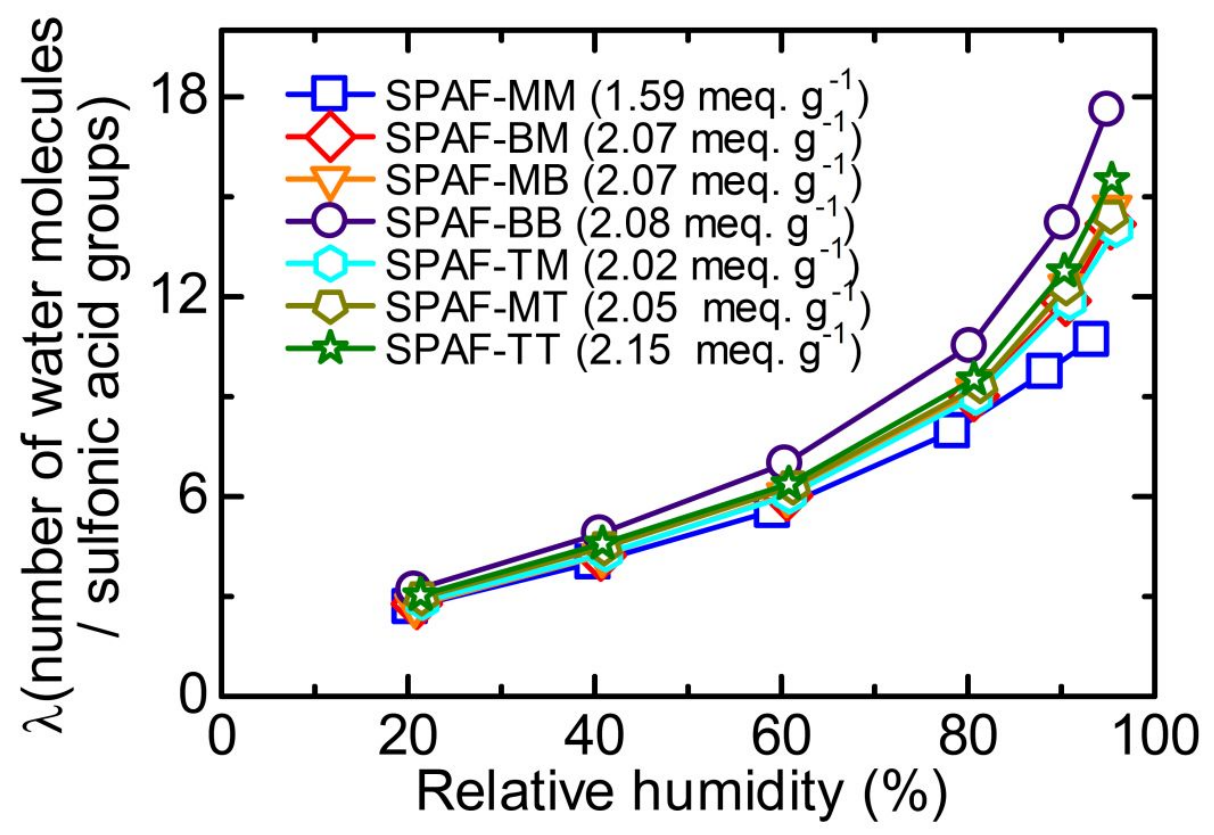

Figure S19. Number of absorbed water molecules per sulfonic acid group $(\lambda)$ values of SPAF membranes at $80^{\circ} \mathrm{C}$ as a function of relative humidity $(\mathrm{RH})$. 


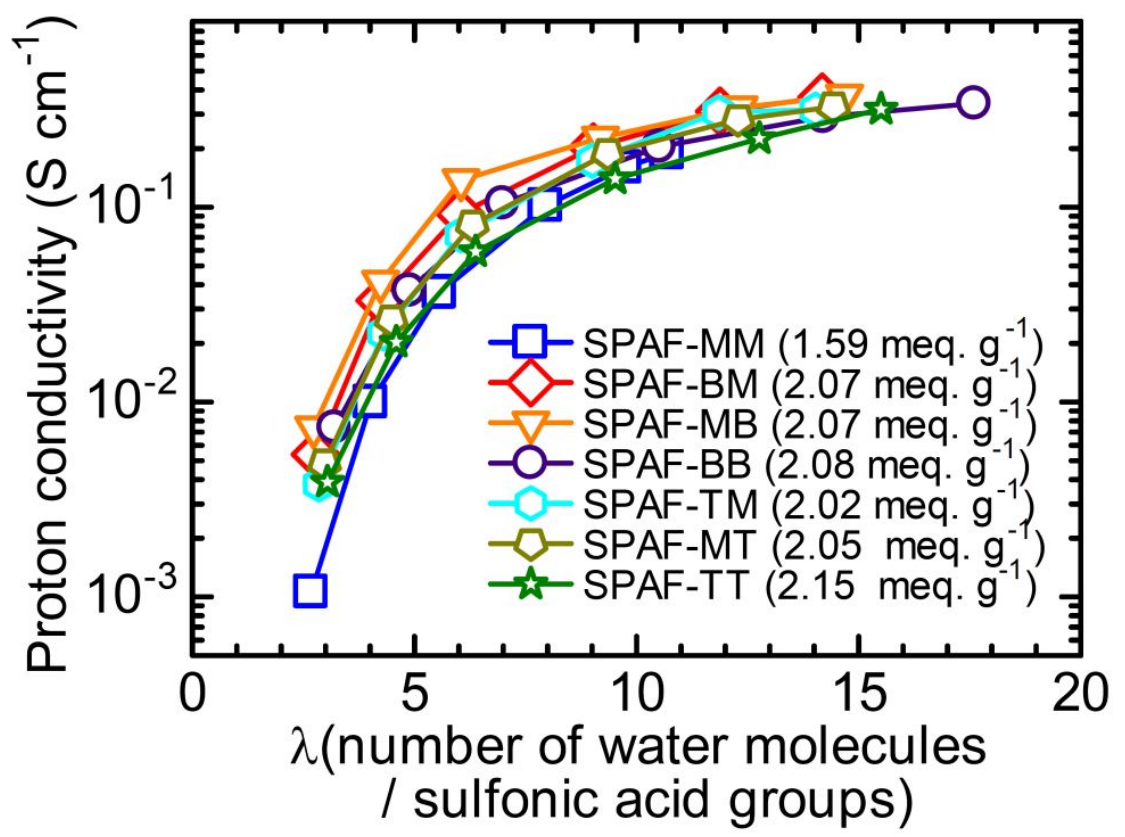

Figure S20. Proton conductivity of SPAF membranes at $80^{\circ} \mathrm{C}$ as a function of $\lambda$. 


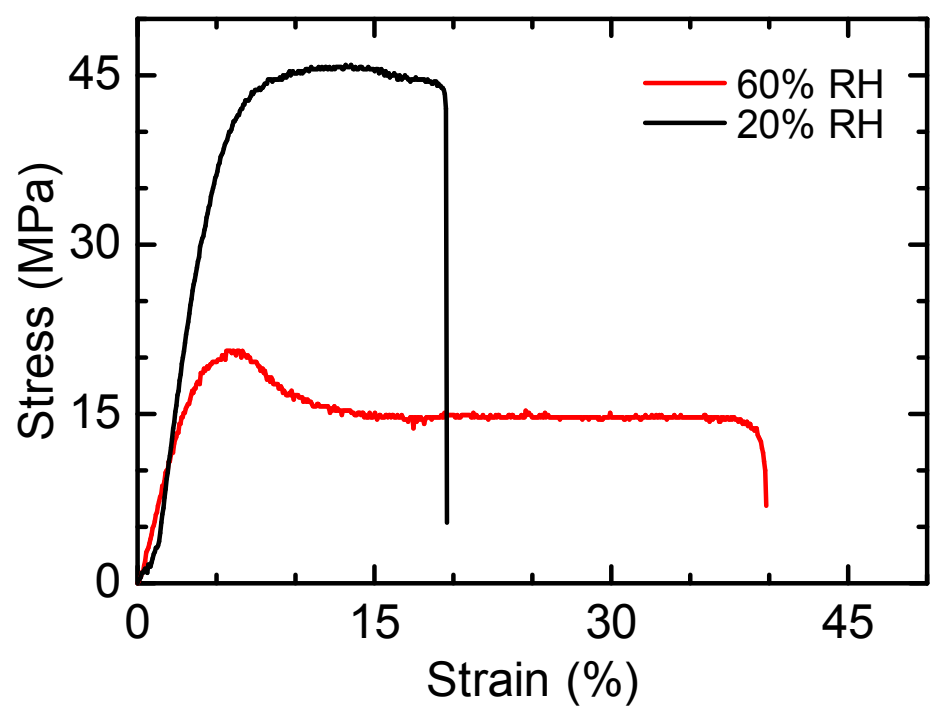

Figure S21. Stress versus strain curves of SPAF-BM membrane at $80{ }^{\circ} \mathrm{C}$. 


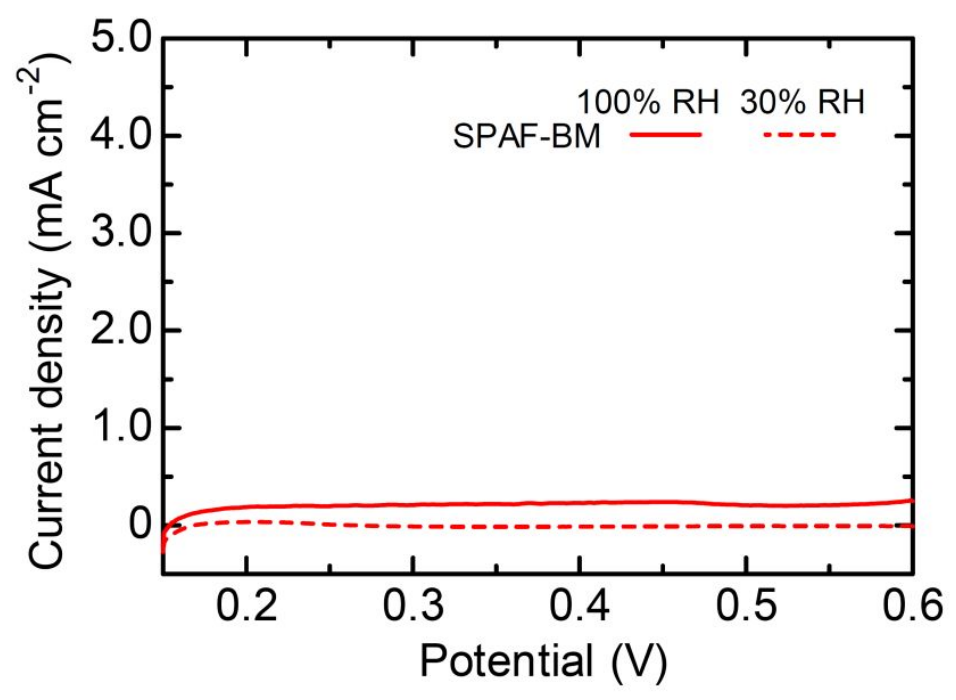

Figure S22. Linear sweep voltammograms (LSVs) of the fuel cell using SPAF-BM (2.07 meq g-1, $23 \mu \mathrm{m})$ membrane at $80^{\circ} \mathrm{C}$. 


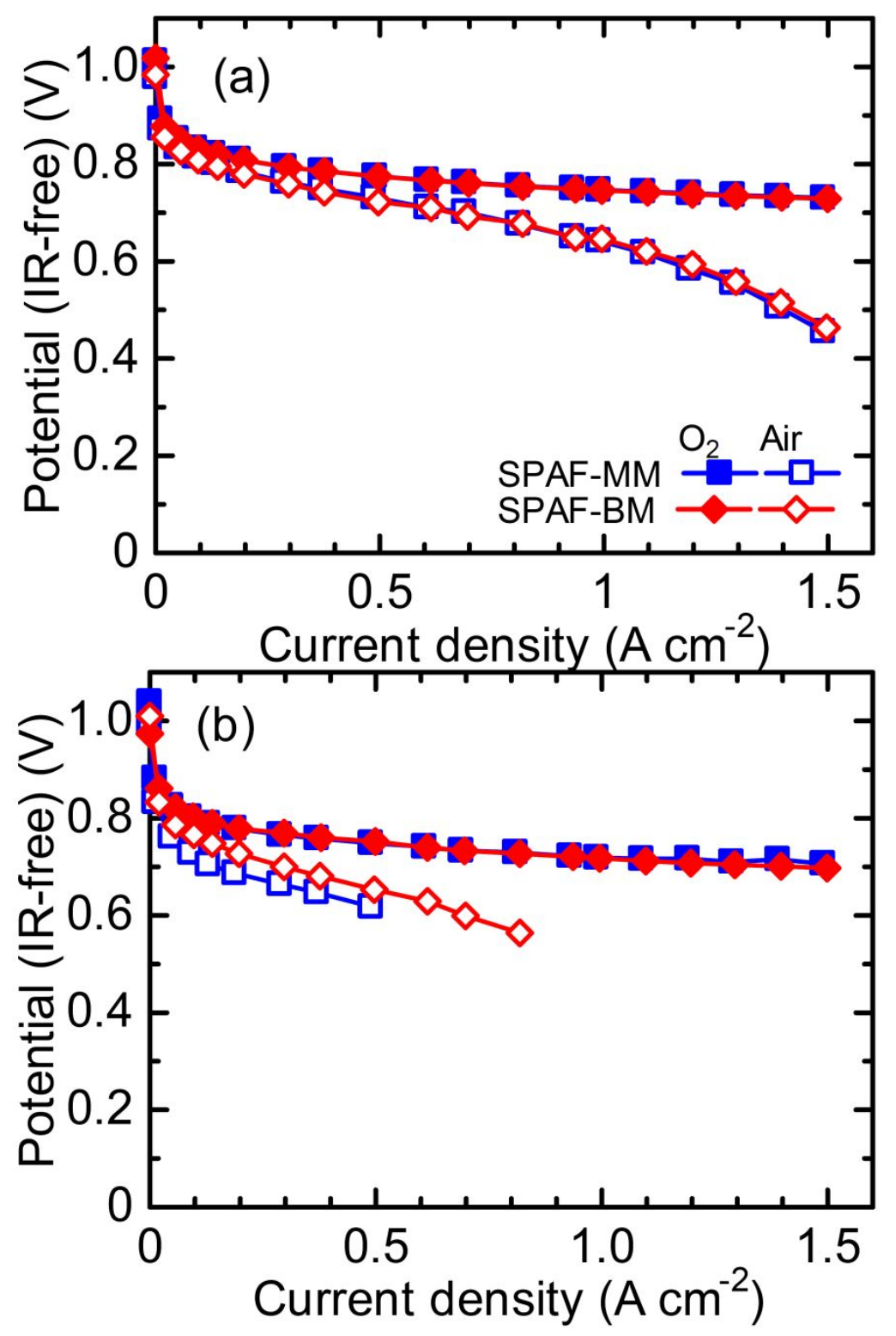

Figure S23. IR-free polarization curves for the SPAF-MM $\left(1.59 \mathrm{meq} \mathrm{g}^{-1}, 28 \mu \mathrm{m}\right)$ and SPAF-BM (2.07 meq g- ${ }^{-1}, 23 \mu \mathrm{m}$ ) cells at $80{ }^{\circ} \mathrm{C}$, (a) $100 \%$ and (b) $30 \% \mathrm{RH}$. The Pt loading amounts were $0.5 \pm 0.05 \mathrm{mg} \mathrm{cm}^{-2}$ for both electrodes. Pure hydrogen and oxygen / air were supplied to the anode and cathode, respectively, without back pressure. The gas utilizations at the anode and the cathode were $70 \%$ and $40 \%$, respectively. 
Table S2. Mass Activity (MA) of Pt Catalysts at $0.85 \mathrm{~V}\left(\mathrm{~A} \mathrm{~g}_{\mathrm{Pt}^{-1}}{ }^{-1}\right.$

\begin{tabular}{ccccc}
\hline \multirow{2}{*}{ cell } & \multicolumn{2}{c}{ MA at $100 \% \mathrm{RH}$} & \multicolumn{2}{c}{ MA at 30\% RH } \\
\cline { 2 - 5 } & $\mathrm{H}_{2} / \mathrm{O}_{2}$ & $\mathrm{H}_{2} /$ Air & $\mathrm{H}_{2} / \mathrm{O}_{2}$ & $\mathrm{H}_{2} /$ Air \\
\hline SPAF-BM & 107.5 & 49.6 & 54.4 & 28.2 \\
SPAF-MM & 102.9 & 52.8 & 51.4 & 16.2 \\
\hline
\end{tabular}



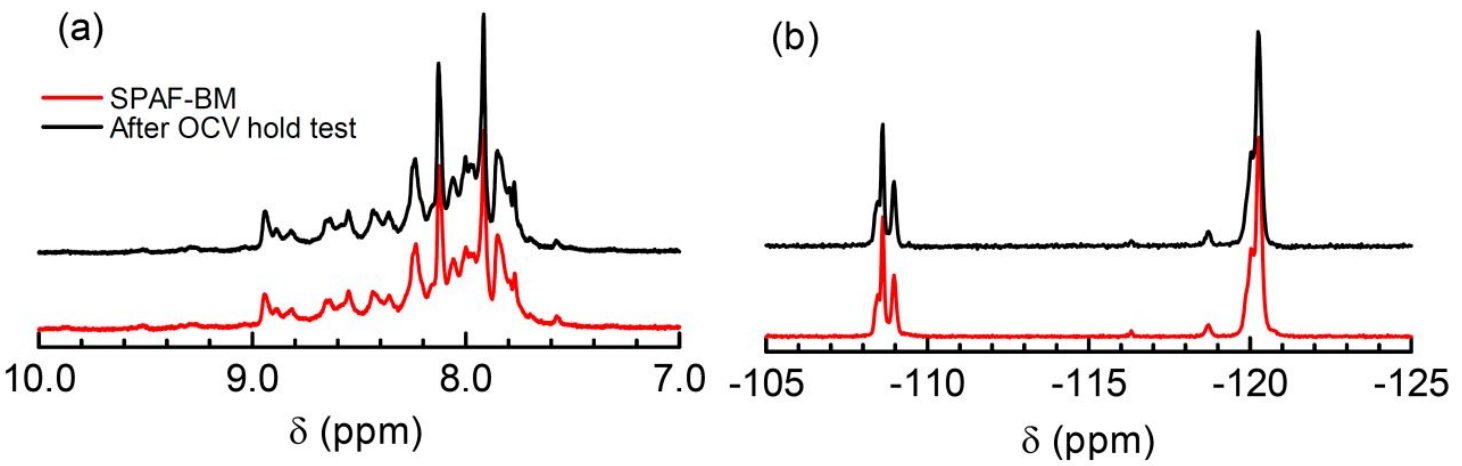

Figure S24. (a) ${ }^{1} \mathrm{H}$ and (b) ${ }^{19} \mathrm{~F}$ NMR spectra of SPAF-BM membrane in DMSO- $d_{6}$ at $80{ }^{\circ} \mathrm{C}$ before and after the OCV hold test for $1000 \mathrm{~h}$. 


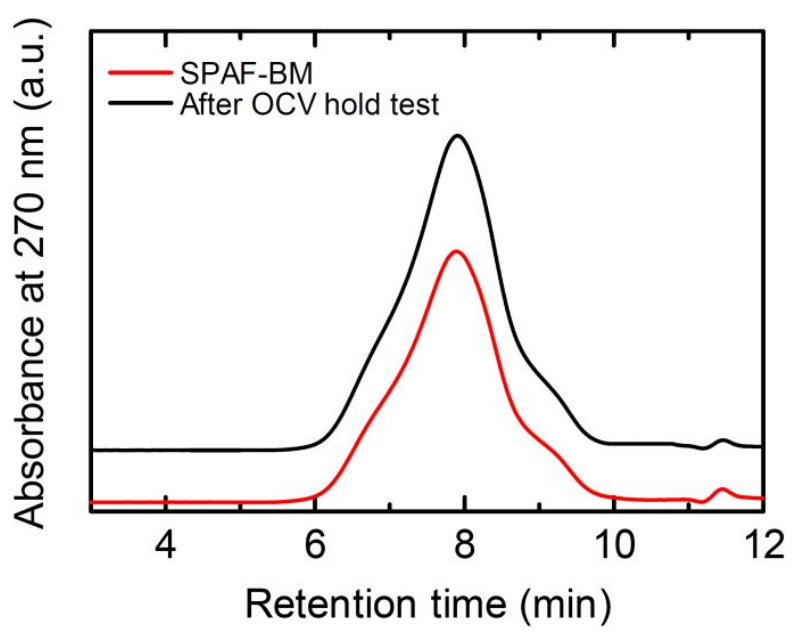

Figure S25. GPC profiles of SPAF-BM membrane before and after the OCV hold test for $1000 \mathrm{~h}$. 


\section{REFERENCE}

(1) Mochizuki, T.; Uchida, M.; Miyatake, K. Simple, Effective Molecular Strategy for the Design of Fuel Cell Membranes: Combination of Perfluoroalkyl and Sulfonated Phenylene Groups. ACS Energy Lett. 2016, 1, 348-352. 